\title{
Software w szkolnym kształceniu polonistycznym, czyli o znaczeniu aktualizacji teorii dydaktycznych
}

\section{Software in Polish school education: about the meaning of importance of updating teaching theories}

\author{
$\| \begin{aligned} & \text { Krzysztof Koc } \\ & \text { Uniwersytet im. Adama Mickiewicza w Poznaniu }\end{aligned}$
}

\begin{abstract}
The article contains a starting thesis that the task of Polish language education is not only to introduce young people into cultural tradition, but also explain to them the modern world. The reality surrounding students should be a permanent point of reference in the teaching process. The result of adopting such an assumption is another thesis that requires updating the didactic theories defining the goals and methods of teaching and learning. The article presents various ways (dimensions) of the implementation of this task and an outline of proposals for reading reportages in the perspective of geopoetics as one of the examples of the mentioned update.
\end{abstract}

Key words: didactical theory, actualization, reportages, geopoetics

Streszczenie: Artykuł zawiera tezę wyjściową, że zadaniem edukacji polonistycznej jest nie tylko wprowadzanie młodych ludzi w tradycję kulturową, ale również objaśnianie im świata współczesnego. Rzeczywistość otaczająca uczniów powinna być trwałym punktem odniesienie w procesie nauczania. Skutkiem przyjęcia takiego założenia jest kolejna teza, iż wymaga to aktualizacji teorii dydaktycznych określających cele i sposoby nauczania i uczenia się. W artykule przedstawiono różne sposoby (wymiary) realizacji tego zadania oraz zarys propozycji czytania reportaży w perspektywie geopoetyki jako jeden z przykładów wspomnianej aktualizacji.

Słowa kluczowe: teoria dydaktyczna, aktualizacja, reportaże, geopoetyka

\section{Wiedza potoczna a wiedza specjalistyczna (o szkole i nauczaniu)}

Gdy zadajemy pytanie o to, dlaczego posyła się uczniów do szkoły, otrzymujemy dość spójne zestawienie edukacyjnych idei. Studenci rozpoczynający swoją przygodę z profesją nauczyciela wymieniają na przykład następujące kwestie: szkoła ma przygotowywać do dorosłego życia, rozwijać kompetencje potrzebne przy wykonywaniu różnych zawodów, inspirować i pogłębiać zainteresowania, umożliwiać samokształcenie, przekazywać wiedzę o człowieku, świecie i wartościach, wprowadzać w tradycję i kulturę, wspierać rozwój kompetencji społecznych, uczyć kreatywnego, 
niezależnego myślenia, poprawnego posługiwania się językiem polskim w mowie i piśmie, właściwego odczytywania zróżnicowanych komunikatów językowych i pozajęzykowych, a także interpretowania tekstów kultury (z naciskiem na teksty literackie) ${ }^{1}$.

Przywołane sądy na temat zadań szkoły nie są jednak wynikiem refleksji nad dydaktycznymi teoriami opisanymi w pracach naukowych, ale świadectwem przekonań osadzonych w doraźności, medialnym dyskursie o szkole, praktyce oceniania jakości pracy nauczyciela i szkoły przez pryzmat wyników egzaminów czy innych wymiernych osiągnięć uczniów (np. dotarcie do finału olimpiady czy konkursu przedmiotowego) oraz w wewnętrznej teorii nauczania odwołującej się do własnych szkolnych doświadczeń i emocji.

Tymczasem podstawą i warunkiem metodycznego myślenia koncepcyjnego jest odwołanie do teorii dydaktycznych, a więc refleksji specjalistycznej, wynikającej ze studiowania i znajomości prac dotyczących kształcenia polonistycznego, także tych sięgających swymi korzeniami daleko w przeszłość, oraz świadomości metodologicznych implikacji i związków, w jakie wchodzi dydaktyka szczegółowa z innymi naukami. Integralny element myślenia koncepcyjnego stanowi również wnikliwa analiza rzeczywistości, w jakiej edukacja polonistyczna (czy szerzej - humanistyczna) jest realizowana, oraz poszukiwanie odpowiedzi na pytanie, jak ją uwzględniać w procesie nauczania i uczenia się. Łatwo więc dostrzec, iż wiedza ekspercka jest jakościowo odmienna od potocznych przekonań o zadaniach szkoły, mimo że odnosi się do tych samych kwestii.

Trudno przecenić znaczenie teorii w myśleniu o tym, czego, jak i po co uczyć na lekcjach języka polskiego. Nie można jej traktować jak klucza otwierającego dostęp do zawsze sprawdzonych, funkcjonalnych, pewnych rozwiązań, które należy wdrożyć. Teoria jest bowiem uzależniona jest od różnorodnych kontekstów, w jakich powstała, i od rzeczywistości - kulturowej, społecznej, politycznej, edukacyjnej, z której wyrastała i ku której się zwracała. Bezrefleksyjne przenoszenie sformułowanych w jej obrębie ustaleń w odmienną rzeczywistość może być tak samo wątpliwym rozwiązaniem, jak wspomniane na początku odwoływanie się wyłącznie do sfery praktyki.

Trafne więc wydaje się posłużenie $\mathrm{w}$ tym przypadku określeniem „aktualizacja”, przejętym na potrzeby objaśnianego tu problemu z języka

\footnotetext{
${ }^{1}$ Takie oczekiwania wobec szkoły formułują studenci rokrocznie na zajęciach z metodyki nauczania języka polskiego prowadzonych przeze mnie, a poświęconych refleksji nad tym, jak postrzegana jest szkoła i jej zadania. Refleksja ta rozpoczyna cykl zajęć wprowadzających w istotę myślenia metodycznego jako myślenia specjalistycznego, osadzonego w teoriach dydaktycznych jako uzasadnień dla rozwiązań praktycznych. Postulaty te dobrze wpisują się w społecznie oczekiwany profil osoby wykształconej, o którym Allen T. Pearson, analizując związki między teorią a praktyką nauczania, pisał: „Ideał wykształconej osoby zawiera zwykle, poza wiedzą z różnych dziedzin nauki, także poznanie różnych spraw społecznych, ludzkich i zawodowych. Społeczeństwo chce, aby młodzi ludzie nabyli pewną wiedzę o świecie zawartą w poszczególnych dyscyplinach naukowych, ale pragnie także, by wyrobili sobie pewne postawy, wartości, upodobania i standardy zachowania, określające po części to, jakimi osobami staną się w przyszłości”. Pearson A.T., 1994, Nauczyciel. Teoria i praktyka w kształceniu nauczycieli, Janowski A., Jankowski M. (przeł.), Warszawa, s. 24.
} 
informatycznego. Systematyczne aktualizowanie programów w komputerze pozwala chronić system; daje poczucie bezpieczeństwa, gdyż udostępniane aktualizacje są z kolei odpowiedzią na dostrzeżone przez specjalistów luki, błędy i zagrożenia, które mogą prowadzić nie tylko do nieodwracalnych strat (np. danych), niezaplanowanych modyfikacji programów, ale nawet do niezauważonego przejęcia kontroli nad działaniami podejmowanymi w wirtualnym i rzeczywistym świecie ${ }^{2}$.

\section{Wymiary aktualizacji}

Aktualizowanie teorii dydaktycznych jest właściwie koniecznością, a nie możliwością. Są one przecież nieodłączną częścią myślenia koncepcyjnego, nierzadko uzasadniają jego celowość i funkcjonalność, jak również umożliwiają ocenę jego skuteczności i jakości. Warto zatem zwrócić uwagę na kilka aspektów aktualizowania teorii, czyli różnych sposobów rozumienia istoty tego procesu:

1. Dostosowanie szkolnej edukacji polonistycznej oraz urzeczywistnianych za jej pośrednictwem teorii do aktualnych, potwierdzonych naukowo, tendencji $w$ sposobie postrzegania świata, kultury itp. oraz form i jakości uczestnictwa we współczesnej rzeczywistości (tu istotna byłaby analiza odnosząca się bezpośrednio do uczniów). Problematyka objęta tego typu aktualizacją dotyczyć może na przykład refleksji nad kryzysem czytelnictwa, wpływem korzystania z mediów cyfrowych na jakość i przebieg aktu lekturowego, trudnościami wynikającymi z czytania powierzchownego, wartościami cenionymi przez młodych itp. Z tej perspektywy warto na przykład przyjrzeć się typom postaw czytelniczych (Polakowski 1980) i sprawdzić, czy zaproponowana przez niego typologia nadal obowiązuje i w jakim zakresie można by ją uzupełnić czy zmodyfikować. Czy postawy takie jak poznawcza, ludyczna, estetyczna i kompensacyjna z dzisiejszej perspektywy wyczerpują wszystkie możliwości, jakie są między nimi zależności ${ }^{3}$, jak je należy dzisiaj zdefiniować? Oto egzemplifikacja

${ }^{2}$ Te niepokojące zjawiska związane choćby z ekspansją Internetu opisuje Wojciech Orliński. Pisze o zagrożeniach dla wolności wyboru i wolności słowa, ograniczeniu praw jednostki, utrudnionym dostępie do informacji, pozbawianiu prywatności itp. We wstępie stwierdza: „Niezależnie od tego, co nowy wspaniały cyfrowy świat ma do zaoferowania każdemu z nas jako jednostce, wszyscy powinniśmy się martwić skutkami społecznymi. Nawet mieszkańcy NRD nie byli inwigilowani przez Stasi tak skutecznie, jak my jesteśmy codziennie inwigilowani przez sektor prywatny i publiczny. Nigdy w historii ludzkości nie pojawiła się sytuacja, w której wolność słowa, tajemnica korespondencji czy przepływy pieniędzy zależały od kilku korporacji, których działalność nie podlega regulacji”. Orliński W., 2013, Internet. Czas się bać, Warszawa, s. 9. To nie tylko wyzwania dla instytucji i firm zajmujących się poprawieniem stanu bezpieczeństwa w sieci m.in. przez dostarczanie odpowiednich aktualizacji, ale też bardzo ważne wyzwanie edukacyjne, również dla kształcenia polonistycznego. W tym przypadku zasadne byłoby więc mówienie o aktualizowaniu problemów istotnych dla współczesnego świata, które warto poruszać na lekcjach języka polskiego. Zob. opisane dalej aspekty aktualizowania teorii.

3 Bożena Chrząstowska, relacjonując ustalenia Polakowskiego, zauważyła, że wymienione postawy „tworzą swoistą hierarchię. Najczęściej manifestują uczniowie postawę poznawczą, najrzadziej pojawia się estetyczna". Charakteryzując i przedstawiając je w tabelarycznej formie, poznańska 
problemów badawczych, przed jakimi staje współczesna dydaktyka polonistyczna. Wymagają one rzetelnej odpowiedzi, gdyż bez takiej analizy trudno sobie wyobrazić jakąkolwiek sensowną koncepcję kształcenia literacko-kulturowego wychodzącą naprzeciw aktualnym potrzebom edukacyjnym młodych ludzi.

2. Powiązanie szkolnej edukacji polonistycznej $z$ refleksją nad współczesną sytuacją kulturową, geopolityczną, społeczną itp. W tym kontekście uzasadnione byłoby na przykład przemyślenie tematów/problemów, które należałoby poruszać na lekcjach języka polskiego oraz tekstów otwierających obszar możliwej refleksji, także wchodzących $\mathrm{w}$ intertekstualne relacje z dziełami dotąd często w szkole omawianymi (Koziołek 2006, Koziołek 2017). Takimi zagadnieniami godnymi szkolnego namysłu mogą być kwestie związane z globalizacją, wielokulturowością, relacjami między ideą a ideologią, migracjami, wpływem mediów (także społecznościowych) na sposób myślenia, komunikowania się i wartościowania, źródłami myślenia ksenofobicznego, przemocą (zarówno w wymiarze indywidualnym, jak i zbiorowym), kulturą popularną i jej wpływem na kształtowanie się tożsamości itp.

3. Rewizja ustaleń teoretycznych składających się na dorobek polskiej myśli dydaktycznej. Polegałaby ona na sprawdzaniu tkwiącego w nich edukacyjnego potencjału na lekcjach czy na przykład $\mathrm{w}$ proponowanych rozwiązaniach podręcznikowych lub w zadaniach egzaminacyjnych oraz na odnalezieniu odpowiedzi na pytanie, w jakiej mierze pozwalają one rozwikłać metodyczne problemy i wspierać proces kształcenia językowego, literacko-kulturowego, emocjonalnego... ${ }^{4}$. W tym przypadku należałoby przyjrzeć się ustaleniom zawartym w pracach dydaktycznych poświęconych np. podmiotowości ucznia i nauczyciela, dydaktyce czynnościowej, antropocentryzmowi oraz sposobom urzeczywistniania tych idei edukacyjnych w szkolnej praktyce. Można by wówczas określić, w jakim stopniu szkolna edukacja polonistyczna wspiera proces rozumienia świata, wartości

badaczka dodała: „Powyższe zestawienie (...) poucza nie tylko o różnorodności postaw czytelniczych młodzieży, ale zwraca uwagę na różną ich wartość, kiedy przyjmujemy edukacyjny punkt widzenia". Chrząstowska B., 1987, Lektura i poetyka. Zarys problematyki kształtowania pojęć literackich w szkole podstawowej, Warszawa, s. 95-97. Ekspansja mediów cyfrowych, kultury obrazu, zainteresowanie rzeczywistością wirtualną czy nowe formy komunikacji (także literackiej) nie tylko odcisnęły ślad na sposobie myślenia dzieci i młodzieży, ale też znacząco kształtują ich postawę wobec dzieła literackiego. Cenne byłoby rozpoznanie tych postaw, zwłaszcza w kontekście ustaleń Polakowskiego czy Chrząstowskiej, które powstały w odmiennej rzeczywistości edukacyjnej, społecznej, kulturowej i politycznej. Być może okaże się, że weryfikacji wymaga sama charakterystyka tychże postaw, ale też nie można odrzucić przypuszczenia, iż konieczne będzie wyodrębnienie jeszcze innej, która nie występowała wcześniej. Wobec powszechnego przekonania o kryzysie czytania interesujące byłoby przeanalizowanie tego, które z postaw występują najczęściej, a które najrzadziej i dlaczego. Taka aktualizacja teorii może otworzyć z kolei drogę do przemyślenia na nowo realizowanej w szkole powszechnej koncepcji kształcenia literacko-kulturowego.

${ }^{4}$ Tak zweryfikowana teoria mogłaby dostarczać cennych narzędzi wspierających realizację zadań edukacyjnych opisanych w punkcie 1 i 2 . 
i drugiego człowieka, a w jakim podporządkowana jest jedynie wyposażeniu młodego człowieka $\mathrm{w}$ narzędzia literaturoznawcze i językoznawcze wymienione $\mathrm{w}$ podstawie programowej, a więc w dość wąską wiedzę specjalistyczną, która w niewielkim stopniu umożliwia uczniom refleksję nad otaczającą ich rzeczywistością kulturową, społeczną, językową.

Przemyślane na nowo koncepcje teoretyczne mogą pomóc $\mathrm{z}$ kolei $\mathrm{w}$ wypracowaniu dydaktycznych innowacji oraz zredefiniowaniu sposobów realizowania edukacji humanistycznej i wspierać na przykład rozwijanie krytycznego myślenia, nauczanie komunikacyjne, otwarte postrzeganie tradycji, „odnowione” interpretacje tekstów od dawna czytanych w polskiej szkole ${ }^{5}$.

Przypomnienie tradycji dydaktycznej pozwala również wartościować obecnie proponowane rozwiązania metodyczne, systemowe czy programowe ${ }^{6}$. Trudno na przykład w literaturze przedmiotu wskazać skuteczniejszą, naukowo lepiej uzasadnioną oraz opracowaną i edukacyjnie bardziej funkcjonalną koncepcję wprowadzania pojęć na lekcjach języka polskiego niż ta, którą w latach 80 . XX wieku przedstawiła Bożena Chrząstowska (Chrząstowska 1987). Rozpoznawanie cech pojęcia przez analizę jego urzeczywistniania się w różnych tekstach, nie tylko literackich, wnikliwa analiza przykładów, uczenie się przez działanie, rezygnacja z podawania definicji terminów na rzecz rozplanowanego w czasie, systemowego, całościowego i metodycznego wprowadzania pojęć, nacisk na ich funkcjonalne wykorzystywanie $\mathrm{w}$ procesie analizowania poszczególnych problemów - to sekwencja postępowania będąca jedyną dotąd przekonującą receptą na myślenie powierzchowne, doraźne i intuicyjne, które nie uczy wnikliwości, krytycyzmu i nie skłania do samodzielnych poszukiwań; ale otwiera się na proste wartościowania i łatwe uproszczenia.

4. Celowe powiązanie składowych elementów procesu dydaktycznego w logiczną całość powinno uwzględniać potrzeby, kompetencje i oczekiwania uczniów oraz obligacje przedmiotu, w tym jego wszystkie istotne wymiary opisane przez Zenona Urygę (Uryga 1996). Aby jednak owa całość odpowiadała również na współczesne wyzwania kulturowe, należałoby ją wpisać w szerszą perspektywę, jaką jest określona filozofia nauczania ${ }^{7}$. To jej urzeczywistnianiu

\footnotetext{
${ }^{5}$ Inspirujące są na przykład odczytania Lalki proponowane przez Ryszarda Koziołka w książce Dobrze myśli się literatura (zob. rozdziały Trzeba kupić tę miłość i Szary geniusz), czy analiza tego samego utworu dokonana przez Janusza Waligórę w pracy Ani rytuał, an karnawał... O interpretacji tekstu literackiego w szkole (ponadgimnazjalnej): warunki - strategie - perspektywy (zob. rozdział Honor albo trzy pojedynki w "Lalce”).

6 Wystarczy przywołać choćby tekstocentryczną koncepcję kształcenia literackiego Kazimierza Wóycickiego czy sceptyczne uwagi i przenikliwe uzasadnienia Michała Głowińskiego wobec realizowanego zwłaszcza w liceum (aż do dzisiaj) historycznoliterackiego kursu kształcenia.

7 Otwarcia edukacji polonistycznej na perspektywę filozoficzną podjęła się Zofia Agnieszka Kłakówna, która zbudowała dydaktyczną, antropocentryczną propozycję podręcznika licealnego (seria
} 
służy bowiem koncepcja metodyczna; co więcej, to właśnie owa filozofia nadaje jej edukacyjny sens ${ }^{8}$. W ten sposób aktualizacja teorii dydaktycznych służyłaby wypracowaniu spójnej i czytelnej koncepcji kształcenia takich rozproszonych dzisiaj obszarów kształcenia polonistycznego jak treści nauczania, ocenianie, egzaminowanie, wychowywanie.

5. Zaadaptowanie do edukacyjnych potrzeb i zadań inspirujących koncepcji literaturoznawczych, nie tylko zawężonych do metodologii lektury (Janus-Sitarz 2009), ale też związanych na przykład z geopoetyką (Rybicka 2014), postkolonializmem (Gandhi 2008), psychologią miejsca (Lewicka 2012).

\section{Aktualizacje a namysł nad światem współczesnym}

U podstaw każdego z opisanych wymiarów aktualizacji teorii dydaktycznych tkwi przekonanie, że konieczne jest otwarcie się na rzeczywistość otaczającą ucznia. Zagrożeniem dla dydaktycznych ustaleń badawczych jest bowiem uznanie wymagań egzaminacyjnych i przekazywania tzw. twardej wiedzy za kategorie nadrzędne, organizujące myślenie o szkolnym nauczaniu. Akceptacja takiego założenia oznacza, że uzasadnione są obawy przed powstaniemznacznegorozziewumiędzymyśleniemokształceniu polonistycznym uprawianym w obrębie uniwersytetów a szkolną praktyką. Jeśli zatem refleksję nad współczesnością uznamy za jeden z konstytutywnych elementów powszechnego kształcenia polonistycznego, to postulowana aktualizacja jest niezbędna. Proponuję więc prześledzić przykładowy jej mechanizm.

$\mathrm{Na}$ początek warto przyjrzeć się profilowi ucznia, którego do takiej refleksji zachęcamy. Okazuje się, że trzeba będzie uporać się z kilkoma problemami wyjściowymi, spośród których należy wymienić kryzys czytelnictwa, powierzchowny i selektywny tryb lektury, trudności z koncentracją i skupieniem uwagi na dłuższym tekście czy wielozadaniowość, która nie tyle sprzyja jakościowemu, pogłębionemu, wielostronnemu myśleniu, ile rozproszeniu uwagi skutkującemu trudnościami z przygotowaniem spójnej, logicznej i strukturalnie uzasadnionej wypowiedzi na dany temat (Spitzer 2016, 63-64). Rozprzestrzeniająca się bardzo szybko „cyfrowa zaraza” (by zacytować tytułową formułę przywoływanej dalej pracy) pozostawia bowiem po sobie skutki w sposobie postrzegania i wartościowania wielu otaczających ucznia zjawisk. Diagnozy dotyczące tej kwestii zawarte np. w raportach Biblioteki Narodowej opisujących stan czytelnictwa w Polsce (Koryś,

To lubię!) na fundamencie Filozofii dramatu Józefa Tischnera. Również Barbara Myrdzik od wielu lat przypomina o edukacyjnym potencjale zawartym w filozofii Gadamera czy Ricoeura.

8 Zob. Koc K., 2011, Filozofia nauczania, w: Innowacje i metody. W kregu teorii i praktyki. Podręcznik akademicki dydaktyki kształcenia polonistycznego, Kwiatkowska-Ratajczak M. (red.), Poznań, s. 47-73. W tym przypadku można oczywiście mówić o filozofiach nauczania urzeczywistnianych za pośrednictwem rozwiązań koncepcyjnych. W dydaktyce nie sposób bowiem wyodrębnić jedną, nadrzędną filozofię edukacyjną, akceptowaną przez ogół badaczy. Stąd tak różne perspektywy rozumienia istoty i celów kształcenia polonistycznego. Ta różnorodność oczywiście sprzyja rozwojowi myślenia koncepcyjnego. 
Kopeć, Zasacka, Chymkowski), jak również prace metodyczne (Kasprzak, Kłakówna, Kołodziej, Regiewicz, Waligóra 2016), publicystyczne (Carr 2013) czy przybliżające odkrycia z zakresu neurobiologii (Spitzer 2012, 2013, 2016) powinny skłaniać środowisko naukowe zajmujące się dydaktyką szczegółową do zredefiniowania np. swoistości barier odbioru opisanych przez Zenona Urygę (Uryga 1982, 70-173) i do przemyślenia na nowo ich genezy. Uzasadnienie takiej potrzeby można odnaleźć w pracach nie tylko ukazujących zagrożenia wywołane ekspansją cyfrowego świata, ale i potencjał, jaki za jego pomocą jest uruchamiany. O szansie, jaką taki proces daje, pisze na przykład Henry Jenkins:

kultura konwergencji jest niezwykle płodna: idee rozprzestrzeniają się z góry na dół zaczynają od mediów komercyjnych i później, gdy rozchodzą się w kulturze, są adoptowane oraz zawłaszczane przez różne grupy publiczności. Inne rozwijają się w dołu do góry - wyłaniają się z różnych miejsc kultury uczestnictwa i zostają wciągnięte do głównego nurtu, jeśli przemysły medialne widzą jakiś sposób, by na tym zarobić. (...) Dlatego powinniśmy interesować się przepływem pomiędzy tymi ośrodkami: rozszerzenie potencjału uczestnictwa to największa okazja do wprowadzenia kulturowej różnorodności. (...) Siła uczestnictwa pochodzi nie z niszczenia kultury komercyjnej, ale i z nadpisywania jej, modyfikowania, poprawiania, rozszerzania, dodawania większej różnorodności rozwiązań i późniejszego wprowadzania ich w obieg, przekazywania ponownie do mediów mainstreamowych (Jenkins 2007, 248).

Jeśli uświadomimy sobie, że kultura komercyjna to przede wszystkim kultura audiowizualna, to warto $\mathrm{w}$ tym kontekście przypomnieć również głos Witolda Bobińskiego, który domagał się uznania edukacji filmowej jako trwałego, a nie okazjonalnego, elementu kształcenia polonistycznego wychodzącego właśnie naprzeciw kulturowej współczesności. Krakowski badacz tak uzasadniał swoją koncepcję:

Fundamentalnym przesłaniem płynącym z wielu strumieni współczesnej refleksji humanistycznej powinno być dla dydaktyki kulturowej uznanie ikoniczności za dominujący paradygmat kultury współczesnej (nie tylko tej popularnej), z czego muszą płynąć wnioski dotyczące zwiększenia szkolnego zainteresowania analizą i interpretacją kulturowych zjawisk wizualnych - innymi słowy: kształtowaniem umiejętności czytania fenomenów kultury wizualnej (Bobiński 2011, 112).

Ten interdyscyplinarny dwugłos należy potraktować przede wszystkim jako egzemplifikację bardzo ważnego problemu teoretycznego - bariera kulturowa może bowiem być mocno związana zarówno ze swoistością konwergencji, jak i z modelowanym przez media cyfrowe sposobem odbioru różnorodnych tekstów oraz współuczestnictwa w ich tworzeniu. Z kolei pominięcie w edukacji szkolnej kwestii związanych z kształtowaniem kompetencji potrzebnych do analizowania i interpretowania języka owych mediów, a przede wszystkim rozumienia istoty oraz funkcji jej ikoniczności prowadzi prostą drogą do utrwalenia mechanizmów sprzyjających powstawaniu bariery postaw i sprawności recepcyjnej. Jedna i druga bariera nie tylko utrudniają realizowanie tradycyjnie rozumianych obligacji przedmiotu, 
czyli kształtowanie sprawności interpretacyjnej, szczególnie w odniesieniu do tekstów literackich (czemu nie zaradzi w żadnym wypadku zadekretowany urzędowo obowiązek czytania wskazanych w podstawie programowej tytułów), ale zakłócają znacząco proces objaśniania skomplikowanych właściwości współczesnego świata.

Wspólnym edukacyjnym mianownikiem warto uczynić w tym kontekście zachęcanie młodych ludzi do poszukiwania złożonych, nieoczywistych odpowiedzi na często pozornie jednoznaczne, a w rzeczywistości bardzo skomplikowane problemy, a de facto pokazywanie czasami trudno uchwytnej granicy między kreacją, perswazją, manipulacją czy nawet przemocą symboliczną, a rzeczywistością, do której te działania się odnoszą i której nadają "jedynie słuszny” sens.

Dlatego tak ważna jest funkcjonalna siatka pojęć, jak i świadomość tradycji kulturowej, która nas określa. Dla teorii dydaktycznej jest to rzeczywisty sprawdzian jej przydatności. Warto jednak pamiętać, że bezrefleksyjne reprodukowanie historycznoliterackiego kursu wiedzy o literaturze, jak przekonywał Michał Głowiński, może właściwie uniemożliwiać zbudowanie spójnej koncepcji dydaktycznej poświęconej światu, w którym uczeń funkcjonuje, porusza się i który wywiera na niego swój wpływ. Tym bardziej cenne jest zarówno przypomnienie zastrzeżeń tego wybitnego literaturoznawcy (Głowiński 1980), jak i dydaktycznych pomysłów Bożeny Chrząstowskiej oraz Zofii Agnieszki Kłakówny9 ${ }^{9}$, które perspektywę współczesną uczyniły punktem wyjścia i trwałym punktem odniesienia w swoich projektach kształcenia zwłaszcza licealnego, uzasadniając je przekonującymi odniesieniami psychologicznymi, pedagogicznymi, filozoficznymi, kulturoznawczymi, literaturoznawczymi oraz oczywiście dydaktycznymi. Można by pokusić się o stwierdzenie, że aktualizując teorię na potrzeby własnych koncepcji, pokazały, że proponowane przez nie innowacyjne myślenie teoretyczne jest przekładalne na sferę szkolnej praktyki - czyli na konkretne lekcje, zadania, a także na zawartość podręcznika jako podstawowej pomocy dydaktycznej.

\section{Geopoetyka i reportaż - sposób czytania współczesnego świata}

Egzemplifikację sposobu aktualizowania teorii dydaktycznej chciałbym zamknąć propozycją odczytywania tajemnic współczesnego świata i człowieka za pośrednictwem tekstów reporterskich i metodycznego wykorzystania w tym celu narzędzi interpretacyjnych oferowanych na przykład przez geopoetykę. Mowa tu zatem o aktualizacji inspirujących koncepcji

9 Zob. np. Uczę się sam... Program nauczania $w$ liceum ogólnokształcacym, liceum profilowanym, technikum, 2002, Chrząstowska B. (oprac.), Poznań; Chrząstowska B., 2007, Jak uczyć rozumienia historyczności w nowym liceum?, „Polonistyka”, nr 7; Kłakówna Z.A., 2016, Koncepcja przedmiotu, w: Język polski. Wykłady z metodyki, Kraków, s. 95-126. Warto też zwrócić uwagę na podręczniki opracowane pod kierunkiem tych dwóch badaczek, czyli serii Skarbiec języka, literatury, sztuki wraz z Wypisami dla klasy I, II i III liceum, 2002-2004, Chrząstowska B. (red.), Poznań oraz To lubię!, 2002-2004, adresowaną do licealistów i uczniów technikum (przygotowaną przez M. Jędrychowską, Z. A. Kłakównę, P. Kołodzieja, E. Szudek, J. Waligórę, E. Łubieniewską, Kraków). 


\section{literaturoznawczych rozumianej jako dostosowanie do edukacyjnych} potrzeb i zadań, w tym przypadku do opisu współczesnego świata. Uzasadnienie dla takiej propozycji można odnaleźć w opisie geopoetyki, definiowanej następująco:

Geopoetykę chciałabym wstępnie zdefiniować jako orientację badawczą, która zmierza w stronę kompleksowego, wieloaspektowego (...) - jednak nie całościowego projektu analizowania i interpretowania interakcji (...) pomiędzy twórczością literacką i praktykami kulturowymi z nią związanymi a przestrzenią geograficzną. Podstawowym zadaniem geopoetyki nie jest wyłącznie badanie reprezentacji, tropienie śladów geograficznych w literaturze, ale stawianie pytań o to, co twórczość literacka czyni - w ramach poetyki i poesis - z owym miejscem czy obszarem. Celem geopoetyki nie będzie zatem „mapowanie” literackich światów, lecz pytanie o to, co dzieje się pomiędzy, w międzyprzestrzeni: pomiędzy „geo” a poetyką, pomiędzy przestrzenią geograficzną a literaturą. Geopoetyka, zgodnie z tym założeniem, nacisk kładzie na dwie strony procesu interakcji, a więc, z jednej strony na doświadczenie miejsc (które siłą rzeczy zakłada podmiotowe zapośredniczenie), a z drugiej strony - odwracając kierunek - na aktywną rolę miejsc w owym doświadczeniu (Rybicka 2014, 92-93).

Analiza reporterskich relacji o świecie (czy to we fragmentach, czy w całości) ${ }^{10}$ wymaga więc, z tej perspektywy, zwrócenia uwagi na kreacyjny wymiar analizowanych narracji. Sprzyjać temu może lektura skupiająca się w pierwszej kolejności na rekonstrukcji własnego odbioru tekstu - co zaskakuje, przeraża, ciekawi, co jest niezrozumiałe, dziwne, co budzi emocje, a co wymaga dodatkowego komentarza. Jak bowiem trafnie zauważa Krystyna Koziołek: „Świadomość tekstualności literatury nie wyklucza zaangażowania w jej pozorny świat znaków, jakby był rzeczywistością" (Koziołek 2017, 106).

Następnie warto się zastanowić nad pytaniami, jakie stawia danemu miejscu reportażysta - co skupia jego uwagę, jakie elementy rzeczywistości budzą jego zainteresowanie, jak wartościuje opisywany świat, jakie znaczenia przypisuje ludziom, tradycji, historii, procesom politycznym czy społecznym ${ }^{11}$.

Kolejnym obszarem zainteresowania trzeba by uczynić język, sposób strukturyzowania opowieści i nadawania znaczeń symbolicznych przedstawianej przestrzeni.

Istotne jest również wyodrębnienie tych cech danego obszaru, które dowodzą jego swoistości i świadczą o jego wyjątkowości (oczywiście

\footnotetext{
${ }^{10} \mathrm{~W}$ tym kontekście warto analizować na lekcjach języka polskiego teksty reporterskie problematyzujące relacje łączące człowieka z przestrzenią; ukazujące zetknięcie się z nią jako okazję do namysłu nad własną i cudzą tożsamością. Takie edukacyjne możliwości stwarza stwarza na przykład analiza Domu żółwia. Zanzibar Małgorzaty Szejnert, Lalek w ogniu. Opowieści z Indii Pauliny Wilk, Świętej ziemi. Opowieści z Izraela i Palestyny Marcina Gutowskiego, Planety Kaukaz Wojciecha Góreckiego czy tomu Piekło jest gdzie indziej Beaty Pawlak. W każdej z tych książek pojawia się refleksja nad pozaeuropejskim sposobem postrzegania świata, charakterystycznym dla danego obszaru geograficznego i kulturowego, który stawia przybyszom z Zachodu wyzwania natury aksjologicznej, kulturowej, politycznej czy religijnej.

11 Cennym źródłem inspiracji do namysłu nad tą kwestią mogą być wywiady z reportażystami i fotoreporterami. Zob. Wójcińska A., 2015, Perspektywa mrówki. Rozmowy z reporterami świata,
} 
z perspektywy doświadczającego tej swoistości podmiotu), oraz tych, które są uniwersalne, ponadkulturowe, zrozumiałe i czytelne dla odbiorcy, który (zgodnie z zamierzeniami opowiadającego) odnajduje w nich inny wariant własnego losu, własnej tradycji historii czy tożsamości. Zgodnie z tezą Rybickiej - to miejsce wpływa na jakość i sposób jego doświadczania, a doświadczenie własne (kompetencje kulturowe, znajomość świata, który się przedstawia, umiejętność dotarcia do ludzi, wysłuchania ich oraz przetworzenia oraz wkomponowania ich wypowiedzi we własną narrację) wpływa na sposób widzenia tego miejsca. ${ }^{12}$

Ważnym ogniwem projektowanych działań byłaby wreszcie refleksja nad tym, jak interpretacja tekstu o obcej rzeczywistości wpłynęła na indywidualny sposób myślenia o sobie, o człowieczeństwie, o wartościach, o innych ludziach i kulturach, czyli w jakim stopniu stała się elementem własnego doświadczenia. Wymaga to oczywiście metodycznego opracowania odpowiednich zadań, poleceń, struktury lekcji, materiałów pomocniczych, które to umożliwią ${ }^{13}$.

Przedstawiony proces „opisywania” świata za pośrednictwem tekstów reporterskich nie jest zamknięty, pełny i nie obejmuje wszystkich istotnych zagadnień. Jednak trudno to uznać za jego wadę - otwiera bowiem możliwość samodzielnego dobierania odpowiednich komponentów przez nauczyciela (zachęca do selekcji tekstów, ich fragmentów, problemów), pozwala na ich modyfikację wynikającą z analizy osiągniętych lub nieosiągniętych celów, uwzględnia także potrzeby i oczekiwania edukacyjne młodych ludzi, jak również cele przypisywane edukacji polonistycznej (czy szerzej - humanistycznej).

Wołowiec lub Borowczyk J., Larek M., 2016, Punkty zapalne. Dwanaście rozmów o Polsce i świecie, Poznań.

${ }^{12}$ Interesującą propozycje proponowanego sposobu „odczytywania” przestrzeni w ten właśnie sposób można odnaleźć w artykule Magdaleny Horodeckiej poświęconym reporterskim opowieściom Wojciecha Góreckiego o Kaukazie. Badaczka tak opisuje ich cechy charakterystyczne: „Dominuje (...) w prozie Góreckiego sposób relacjonowania oparty na strategii nizania kaukaskich doświadczeń i lektur w pewien niezwykle gęsty narracyjny nurt obserwacji, opinii, i interpretacji, tworzący (...) wrażenie obcowania z nieskończoną ilością elementów układających się jednak w uporządkowany ciąg" (Horodecka, 2017, 240). W dalszej części swoich rozważań autorka artykułu zwraca uwagę na to, iż w przypadku tego typu relacji mamy do czynienia z przestrzenią utekstowioną. W konsekwencji, w procesie analizy i interpretacji tekstu należy mieć świadomość wpływu autorskich strategii reprezentacji na sposób rozumienia przez czytelnika odmienności i obcości kulturowej przedstawionej w reportażach. Wydaje się, że w szkolnej praktyce czytania dzieł należących do tego gatunku na ten element raczej nie zwraca się uwagi. A zatem to kolejny argument przemawiający za tym, by aktualizując teorię dydaktyczną, sięgać po narzędzia, jakie proponuje współczesna humanistyka.

13 Przykładowy sposób czytania reportaży w perspektywie geopoetyki można odnaleźć w książce Przemysława Czaplińskiego Poruszona mapa. Wyobraźnia geograficzno-kulturowa polskiej literatury przełomu XX i XXI wieku, Kraków 2016. Jego analizy integrują wszystkie opisane ogniwa pracy z tekstem reporterskim. Szczególnie fascynują analizy utworów opisujących Rosję, które znoszą „przezroczystość” reporterskich opowieści i odsłaniają tkwiącą w nich przedziwną plątaninę uprzedzeń, stereotypów, kreacji, z góry przyjętych założeń, utrwalonych wyobrażeń, narzuconych ocen. Dotyczy to dzieł i autorów uznawanych za autorytety, znawców „rosyjskiej duszy”, takich jak choćby Ryszard Kapuściński, Krystyna Kurczab-Redlich czy Jacek Hugo-Bader. Warto na tę „szkołę czytania” zwrócić uwagę także dlatego, iż refleksja nad relacjami polsko-rosyjskimi oraz samą „rosyjskością" jest jednym z niewielu zagadnień rzeczywiście podejmowanych na lekcjach języka polskiego. Tematykę tę trudno pominąć, pojawia się przy interpretacji Dziadów cz. III, Pana Tadeusza, Lalki, Przedwiośnia, Innego świata, Mistrza i Małgorzaty, Zbrodni i kary, a nawet fragmentów Imperium. 
Nie jest to wersja kształcenia alternatywnego, funkcjonującego poza ramami szkolnictwa powszechnego. Wydaje się, że w systemie edukacji powszechnej trwającej 12 lat jest miejsce na wytyczenie takiego szlaku, by była ona realizacją spójnej, logicznej, całościowej i metodycznej dopracowanej koncepcji dydaktycznej.

Jeśli zatem potraktujemy obowiązujący w Polsce system edukacyjny wraz ze wszystkimi składającymi się na niego uwarunkowaniami instytucjonalno-prawnymi jako odpowiednik informatycznego hardware'u, to realizowane $\mathrm{w}$ jego ramach koncepcje kształcenia, $\mathrm{w}$ tym przypadku - humanistycznego, należy potraktować jako odpowiednik software'u. Ten elementarny podział przypomina, że bez odpowiedniego oprogramowania nawet najlepsze urządzenia komputerowe nie mogą działać ani optymalnie wykonywać swoich skomplikowanych i złożonych funkcji ${ }^{14}$.

Software jako zbiór zróżnicowanych narzędzi pozwala realizować różnorodne zadania indywidualne i społeczne. Jego jakość mierzy się jego funkcjonalnością, poza tym znacząco stymuluje rozwój technologii, a te stymulują rozwój oprogramowania. Jeśli z tej perspektywy spojrzymy na teorie dydaktyczne, to trudno przecenić znaczenie ich aktualizacji, zwłaszcza wobec licznych niedoskonałości systemu i raz po raz wprowadzanych w nim zmian budzących liczne zastrzeżenia i wątpliwości. W tej sytuacji refleksja nad ową aktualizacją może być obszarem łączącym szkołę z uniwersytetem, elementem być może w przyszłości stymulującym zmiany prawno-instytucjonalne oraz źródłem edukacyjnej innowacyjności jako ciągłego, a nie doraźnego procesu namysłu nad tym, po co, jak i czego uczyć.

\section{Bibliografia}

Bobiński Witold, 2011, Teksty w lustrze ekranu. Okołofilmowa strategia kształcenia literacko-kulturowego, Kraków.

Carr Nicholas, 2013, Płytki umysł. Jak Internet wpływa na nasz mózg, Rojek K. (przeł.), Gliwice.

Chrząstowska Bożena, 1987, Lektura i poetyka. Zarys problematyki kształtowania pojęć literackich $w$ szkole podstawowej, Warszawa.

Czapliński Przemysław, 2016, Poruszona mapa. Wyobraźnia geograficznokulturowa polskiej literatury przełomu XX i XXI wieku, Kraków.

Gandhi Leela, 2008, Teoria postkolonialna. Wprowadzenie krytyczne, Serwański J. (przeł.), Poznań.

Głowiński Michał, 1980, Szkolna historia literatury: wprowadzenie w tradycję, w: Olimpiada Literatury i Języka Polskiego. Założenia - oceny - postulaty, Chrząstowska B., Kostkiewiczowa T. (red.), Warszawa.

${ }^{14}$ Daleki jednak jestem od uznania, że zmiany wprowadzone do podstaw programowych dotyczących kształcenia polonistycznego w 2017 i na początku 2018 roku należy ocenić jako nowoczesne i odpowiadające współczesnym potrzebom edukacyjnym młodych ludzi. W niewielkim stopniu zakładają one, że szkoła ma uczuć rozumienia współczesności. Temat ten wymaga osobnego omówienia. Zastrzegam zatem, że proponowany podział na software i hardware jest w tym przypadku figurą myślową, mającą ukazać związki między teorią i praktyką oraz uzasadnić potrzebę aktualizowania tej pierwszej. 
Horodecka Magdalena, 2017, Geograficzne kontinuum reprezentacji. Kaukaz Wojciecha Góreckiego, w: Geograficzne przestrzenie utekstowione, Karwowska B. , Konończuk E., Sidoruk E., Wampuszyc E. (red.), Białystok, s. 235-260.

Janus-Sitarz Anna, 2009, Przyjemność i odpowiedzialność w lekturze. O praktykach czytania literatury w szkole. Konstatacje. Oceny. Propozycje, Kraków.

Jenkins Henry, 2007, Kultura konwergencji. Zderzenie starych i nowych mediów, Bernatowicz M., Filiciak M. (przeł.), Warszawa.

Kasprzak Paweł, Kłakówna Zofia Agnieszka, Kołodziej Piotr, Regiewicz Adam, Waligóra Janusz, 2016, Edukacja w czasach cyfrowej zarazy, Toruń.

Kłakówna Zofia Agnieszka, 2003, Przymus i wolność. Projektowanie procesu kształcenia kulturowej kompetencji. Język polski w klasach IV-VI szkoły podstawowej, w gimnazjum i liceum, Kraków.

Kłakówna Zofia Agnieszka, 2016, Język polski. Wykłady z metodyki, Kraków.

Kołodziej Piotr, 2013, Czas na obraz. Dzieło malarskie jako tekst i kontekst w szkolnym kształceniu humanistycznym (1880-1999), Kraków.

Koryś Izabela, Kopeć Jarosław, Zasacka Zofia, Chymkowski Roman, Stan czytelnictwa $w$ Polsce w 2016 roku. http://www.bn.org.pl/download/ document/1492689764.pdf (dostęp: 20.10.2017).

Koziołek Krystyna, 2006, Czytanie z innym. Etyka. Lektura. Dydaktyka, Katowice.

Koziołek Krystyna, 2017, Czas lektury, Katowice.

Koziołek Ryszard, 2016, Dobrze myśli się literatura, Wołowiec.

Lewicka Maria, 2012, Psychologia miejsca, Warszawa.

Myrdzik Barbara, 1999, Rola hermeneutyki w edukacji polonistycznej, Lublin.

Myrdzik Barbara, 2006, Zrozumieć siebie i świat. Szkice i studia o edukacji polonistycznej, Lublin.

Nussbaum Martha C., 2008, W trosce o człowieczeństwo. Klasyczna obrona kształcenia ogólnego, Mączkowa A. (przeł.), Wrocław.

Pearson Allen T., 1994, Nauczyciel. Teoria i praktyka $w$ kształceniu nauczycieli, Janowski A., Jankowski M. (przeł.), Warszawa.

Polakowski Jan, 1980, Badania odbioru prozy artystycznej $w$ aspekcie dydaktycznym. Zarys teorii badań - próby diagnozy, Kraków.

Polonista na rynku pracy. O strategiach dostosowywania kształcenia studentów do wyzwań rynku pracy, 2016, Wobalis M., Gis A. (red.), Poznań.

Rajewicz Danuta, 2012, Telewizja w edukacji polonistycznej. Obszary integracji, kształtowane kompetencje, Poznań.

Rybicka Elżbieta, 2014, Geopoetyka. Przestrzeń i miejsce we współczesnych teoriach i praktykach literackich, Kraków.

Spitzer Manfred, 2012, Jak uczy się mózg, Guzowska-Dąbrowska M. (przeł.), Warszawa.

Spitzer Manfred, 2013, Cyfrowa demencja. W jaki sposób pozbawiamy rozumu siebie i swoje dzieci, Lipiński A. (przeł.), Słupsk. 
Spitzer Manfred, 2016, Cyberchoroby. Jak cyfrowe życie rujnuje nasze zdrowie, Guzowska M. (przeł.), Słupsk.

Uryga Zenon, 1982, Odbiór liryki w klasach maturalnych, Warszawa-Kraków.

Uryga Zenon, 1996, Wymiary przedmiotu, w: Godziny polskiego, WarszawaKraków.

\section{O Autorze:}

Krzysztof Koc - doktor nauk humanistycznych w zakresie literaturoznawstwa, adiunkt w Pracowni Innowacji Dydaktycznych UAM w Poznaniu; autor książki Czytanie świata. Reportaże Ryszarda Kapuścińskiego w edukacji polonistycznej (Poznań 2007) i współautor podręcznika akademickiego dydaktyki kształcenia polonistycznego Innowacje i metody. W kregu teorii i praktyki, pod red. M. Kwiatkowskiej-Ratajczak (Poznań 2011), publikował m.in. w „Polonistyce”. Nauczyciel języka polskiego. Obecnie pracuje nad książką Lekcje myślenia. Metodyka koncepcyjna w edukacji polonistycznej. 
